\title{
D-STATCON model for voltage sag mitigation
}

\author{
Hendri Masdi ${ }^{1}$, Rini Nur Hasanah ${ }^{2}$, Hadi Suyono $^{3}$, Ismail Bin Musirin ${ }^{4}$, Taufik ${ }^{5}$ \\ ${ }^{1}$ Department of Electrical Engineering, Universitas Negeri Padang (UNP), Indonesia \\ ${ }^{2,3}$ Department of Electrical Engineering, Universitas Brawijaya (UB), Indonesia \\ ${ }^{4}$ Faculty of Electrical Engineering, Universiti Teknologi MARA (UiTM), Malaysia \\ ${ }^{5}$ Electrical Engineering Department, California Polytechnic State University (CalPoly), USA
}

\begin{abstract}
Article Info
Article history:

Received Apr 10, 2019

Revised Jun 7, 2019

Accepted Jul 24, 2019

\section{Keywords:}

Distribution network

D-STATCON

Reactive power compensation

Static synchronous condenser

Voltage sag mitigation

ABSTRACT

Development of a FACTS device model for mitigating voltage sag is presented. It deals with a static synchronous condenser (STATCON) to be used in the AC distribution networks. Simulation with the help of a commercial software Matlab/Simulink was explored to investigate its characteristics and performance during the voltage sag occurrence. The considered main cause of voltage sag was the starting of high capacity asynchronous motor. A voltage source inverter based on the phase-controlled thyristor components was implemented in this application to compensate the change in reactive power of the system. The concerns have been put on the influence of initial operation point and DC capacitance. The study results show the capability of D-STATCON model to reduce the consequence of voltage sag following the starting of high-power asynchronous motor in the distribution network. A fast response of the condenser work confirmed the desired performance.
\end{abstract}

Copyright (c) 2019 Institute of Advanced Engineering and Science. All rights reserved.

\section{Corresponding Author:}

Rini Nur Hasanah, Department of Electrical Engineering, Universitas Brawijaya, Jalan MT Haryono 167 Malang 65145 Indonesia.

Email: rini.hasanah@ub.ac.id

\section{INTRODUCTION}

In the old days, it was mostly mechanical equipment which has been used to control industrial processes. The mechanical equipment is much more tolerant to voltage disturbances. Nowadays, many kinds of electronic components are found in modern industrial equipment, like optical devices, programmable logic controllers, and adjustable speed drives. As the electronics components are very sensitive to voltage disturbances, the power utility company must guarantee the quality of power delivered to customers [1-7].

The most often disturbance which may bring problem to electronic devices is voltage sag $[1,3,4,6$ -10]. It is described as a reduction in the effective value of the network voltage at fundamental frequency to the value between 0.1 and 0.9 per unit with the length of time from one-half cycle to one minute. The sag is characterized using both its magnitude and time duration. The duration is normally related to the required time to clear the fault by the protecting devices.

Voltage sags are becoming big problems in many industrial companies $[1-4,6,7]$ and considered to be really disturbing because the events are of random occurrence and lasting only in a very short time. Moreover, they become the most burdensome problem of power quality for many industrial customers today $[3,4]$.

Voltage sags, as indicated in Figure 1, may bring about the damage in equipment, the disturbance of production, or even the tripping of protection relays. The interest in mitigating the voltage sag has been continuously increasing because of the large application of sensitive electronic devices in modern industry. $[1,2,8,9]$. 
This study deals with the voltage sags brought about by the starting of high-power asynchronous motors in the network. The occurrence of voltage sags will slow down the operation of motor, although usually it will not stop the operation unless being tripped by the protective contactors. Bad consequences may occur in a form of torque oscillations which are caused by very deep sags, or the tripping of relays. This situation may be found when high currents are drawn by the motor during starting [2, 11-14].

In an unbalance condition, the sag may also affect the negative-sequence voltage. As the negativesequence of motor impedance is usually low, a large current component of negative-sequence will be absorbed. The current being drawn by motor is also high, making it necessary to build the air-gap flux and accelerate the machine again after the voltage recovery [15]. Consequently, the duration of sag after the fault will be longer in case the load of the motor is larger than the impedance of the system. The reference [16] presented the results of the study about the influence of asynchronous motors on the voltage sags during faults.

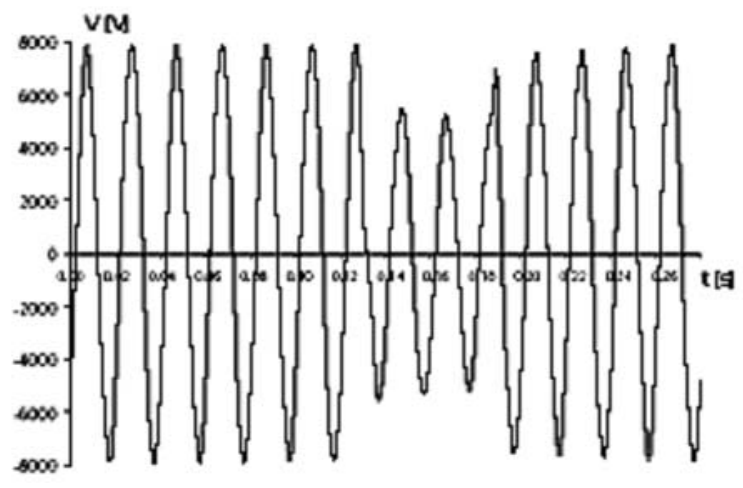

Figure 1. A waveform example of voltage sag

Some measures taken to handle the voltage sags problem are among others using dynamic voltage restorers $[8,11]$, distributed generation units $[12,17]$, and Faraday exchanger [18]. Some other approaches to reduce the voltage sag are the injection of reactive current in shunt connection and the injection of voltage in series connection. A research on the mitigation of voltage sag using the use of single-phase voltage source inverter has been performed in [15]. A static compensator connected in series has been combined with a converter connected in shunt to the load-side [19-22].

A D-STATCON, as being categorized in shunt compensation devices, can be used for sag mitigation [23-25]. The D-STATCON can be obtained using a VSC and a DC bank being charged through a bridge rectifier and a proper control. The D-STATCON is functioning to inject reactive power to the system when the voltage sag occurs. The amount of reactive power can be adjusted by controlling the firing angle of the thyristor or the DC value [20].

The voltage restoration has been implemented using a topology consisting of series and shunt connections $[15,23,24]$. Three single-phase VSIs is connected in series to the supply-side, whereas a 3phase diode rectifier is in shunt connection to maintain the energy of the injected voltage with the dc-link capacitor. The sag detection and compensation control have been based on the phase detection and the synchronously rotating reference-frame transformation.

This paper presents a D-STATCON model for voltage sag mitigation. It explores the development of a thyristor-based D-STATCON model and its behavior and compensation capability performance in mitigating the voltage sags caused by asynchronous motors starting [11-14].

\section{RESEARCH METHOD}

D-STATCON is commonly used to overcome the reactive power problem in the distribution network being caused by load variation. An unacceptable voltage variation may be resulted following the reactive power unbalance. It can be used in a network with a bad power factor or often voltage regulation, even if the most often application is to overcome the voltage stability problem $[6,16]$. The D-STATCON is capable of acting faster than a static VAR compensator (SVC), supporting the grid stability by continuously providing variable reactive power in response to voltage variations.

\subsection{Basic functioning of D-STATCON}

D-STATCON model for voltage sag mitigation (Rini Nur Hasanah) 
A STATCON is functioning based on the principle of voltage source converter (VSC). The voltage source is resulted from a DC capacitor, making it have very little active power capability. This drawback may sometimes be overcome by providing an energy storage device which is added to the DC capacitor. The shunt-connected FACTS devices like a D-STATCON offer more advantages than a series device. They can also be used at the same time to control the steady-state voltage, to damp the oscillation of load power, and also as a back-up power source. Some applications of D-STATCON for mitigating the voltage sag are presented in $[10,25]$.

As shown in the basic functional model of a STATCON in Figure 2, the amplitude of the voltage source is adjusted to control the reactive power at the terminals of STATCON. The STATCON will generate reactive current when the $\mathrm{AC}$ voltage at the point of connection is less than the converter voltage, and vice-versa.

The response time of a STATCON is shorter than that of an SVC, especially due to the fast switching times provided by the type of components used in the converter. It also provides a better support in reactive power at low AC voltage condition than an SVC does. It is because the resulted reactive power decreases linearly when the AC voltage decreases, by maintaining the current at the rated value even at a low AC voltage [26-31]. As it involves only reactive power, there is no phase difference between the voltage of the D-STATCON output and the AC system, when circuit losses are neglected. The phase of current drawn from the D-STATCON is 90 o shifted with respect to the phase of AC system voltage, whether it can be leading (generating reactive power) or lagging (absorbing reactive power).

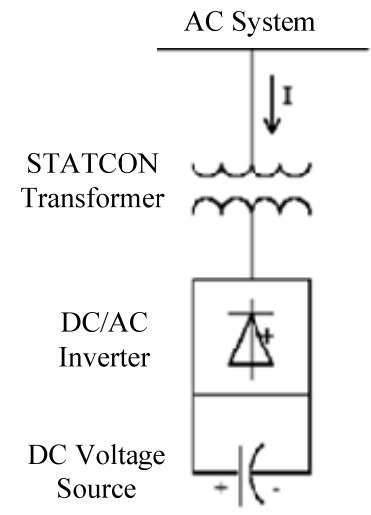

Figure 2. D-STATCON functional model

\subsection{Control principle of reactive power}

The flow of reactive power between the D-STATCON and the AC voltage system is undertaken by adjusting the output voltage of D-STATCON with respect to that of the AC system voltage in order to adjust the amount and type of reactive power (capacitive or inductive) to be supplied to the AC system. The reactive power to be supplied is given by

$$
Q=\frac{V_{D-S T A T C O N}-V_{S}}{X} V_{S}
$$

where $Q$ represents the reactive power to be exchanged, $V_{\text {D-STATCON }}$ is the magnitude of the D-STATCON output voltage, $V_{\mathrm{s}}$ is the magnitude of the system voltage, and $X$ is the equivalent impedance between $\mathrm{D}$ STATCON and the AC system. The positive value of $Q$ means that reactive power is supplied to the system by D-STATCON, and vice-versa.

\subsection{Simulation model}

The simulation model of D-STATCON for the purpose of voltage mitigation being caused by asynchronous motor starting is given in Figure 3. As indicated, it comprises a three-phase voltage-sourced

Int J Pow Elec \& Dri Syst Vol. 10, No. 4, Dec 2019 : 2214 - 2221 
inverter to form the output voltage wave. To maintain the dc-source energy, six uncontrolled switches (diodes) have been used. The inverter bridge and diodes bridge are connected together and then being connected to the grid via a transformer.

The injection of current to the AC voltage system is performed by the inverter bridge of the DSTATCON. As shown in Figure 4, the D-STATCON will supply the VARs to the system when the voltage of D-STATCON output is higher than that of the system. Otherwise, the flow of reactive power exchange will be reversed.

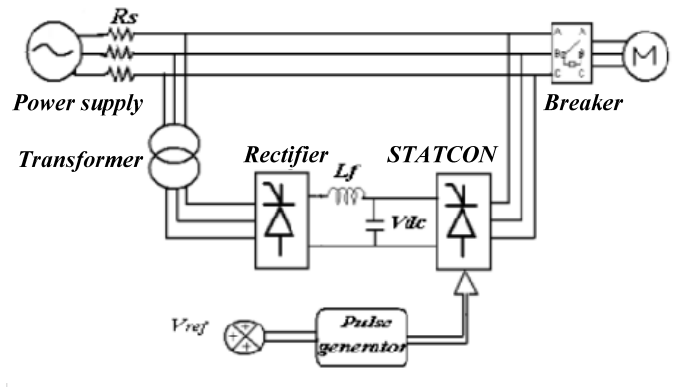

Figure 3. D-STATCON simulation circuit

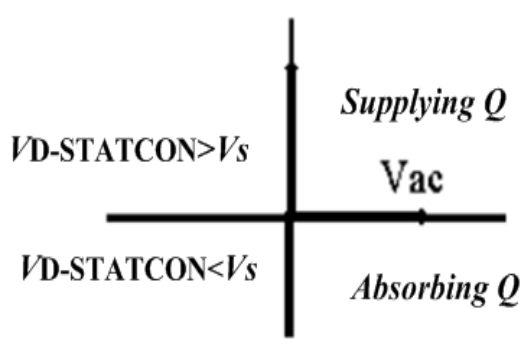

Figure 4. Generation and absorption of reactive power, where $V_{\mathrm{D}-\mathrm{STATCON}}$ is D-STATCON output voltage and $V_{\mathrm{s}}$ is the terminal voltage

\section{RESULTS AND ANALYSIS}

The circuit shown in Figure 3 was simulated with the help of Matlab/Simulink software. Two cases were considered; the first one was the system simulation without D-STATCON, whereas the second one was with the use of the D-STATCON. In both conditions, it was assumed that the starting of asynchronous motor occurred 0.25 second after the initial time of system operation.

The voltage waveforms of the system with and without D-STATCON are given in Figure 5. As can be observed, the magnitude of the voltage sag is of $76 \%$ in magnitude and the related duration is around 0.53 sec. Figure 5a represents the line voltage waveform at load terminal during the voltage sag occurrence before the implementation of D-STATCON in the system, whereas Figure 5b shows that when the D-STATCON has been implemented in the system. It can be clearly seen in Fig. $5 \mathrm{~b}$ that there is an improvement of the voltage magnitude to $91 \%$ during $0.13 \mathrm{sec}$, being compared to Fig. 5a showing when the D-STATCON was not in operation.

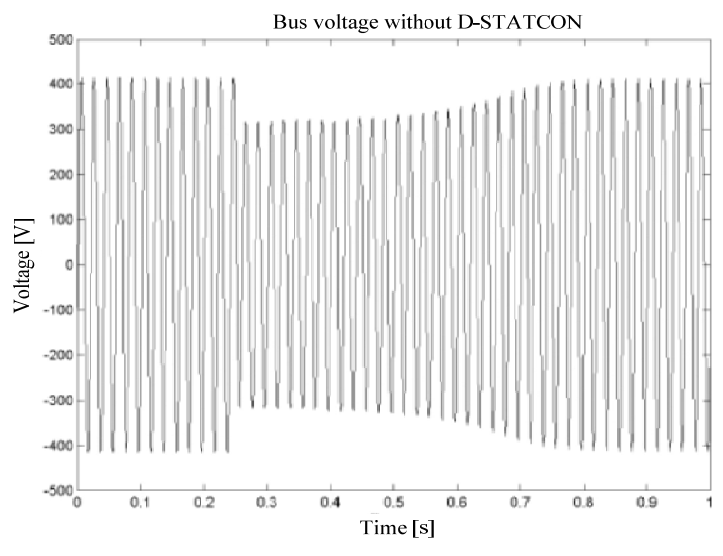

(a)

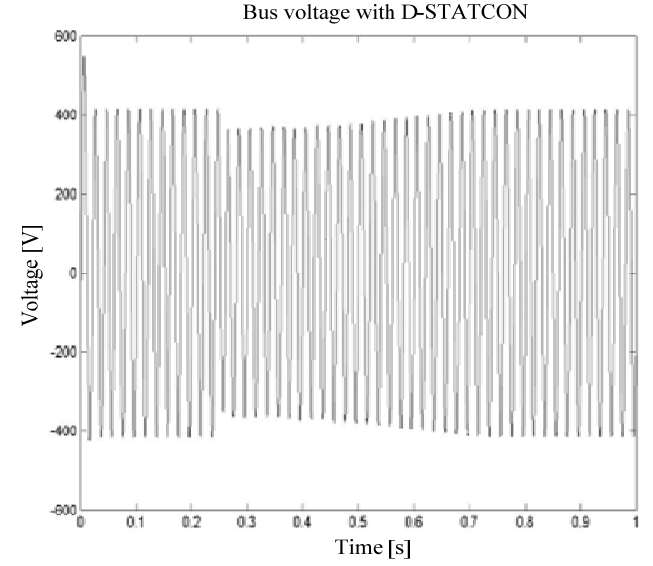

(b)

Figure 5. Line voltage waveforms, (a) without D-STATCON, (b) with D-STATCON 
The injection of active and the reactive powers to the system by the D-STATCON during the event of voltage sag is presented in Figure 6. As seen, both the active and reactive powers are positive. It means that during the voltage sag occurrence, the load absorbs both active and reactive power. The thyristor-firing angle determines the amount of reactive power to be supplied, as shown in Table 1.

Table 1. Changes of reactive power with respect to firing angle

\begin{tabular}{cc}
\hline Firing angle (degree) & Reactive power (VAR) \\
\hline 140 & 380 \\
145 & 700 \\
150 & 960 \\
155 & 1180 \\
160 & 1360 \\
165 & 1560 \\
170 & 1780 \\
175 & 2000 \\
\hline
\end{tabular}

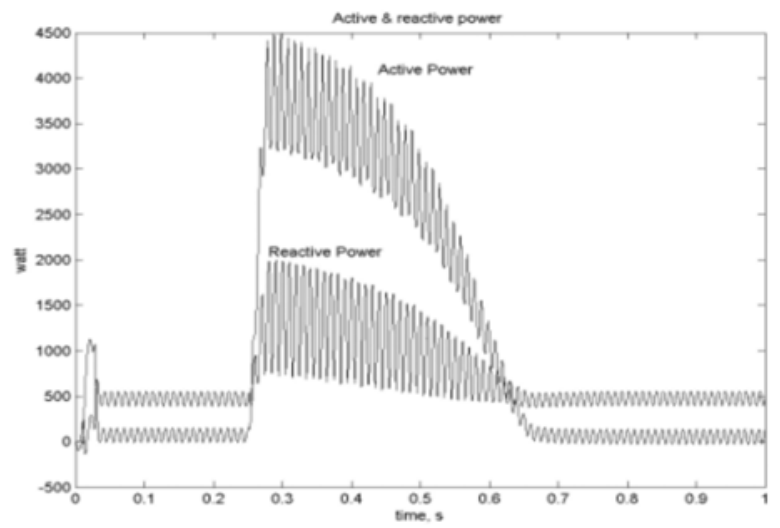

Figure 6. The active and reactive powers generated by the D-STATCON

Figures $7 \mathrm{a}, 7 \mathrm{~b}$ and 8 show the effect of implementing D-STATCOM in the system. Figure 7a shows the load current waveform before the D-STATCON was used in the system, Figure 7b indicates that with the implementation of D-STATCON in the system, whereas Figure 8 presents the waveform of current being drawn by the D-STATCON. It shows that the D-STATCON voltage level is higher than that of the system. It is also observable that there is a small current drawn by the D-STATCON but has no effect on the system. 
Figure 7. Load current waveforms, (a) without D-STATCON, (b) with D-STATCON

As can be observed in Figure $7 \mathrm{~b}$, the voltage sag is occuring during the interval time from 0.25 second up to 0.65 second, and it is during this period of time that the D-STATCON is producing the current injection into the system, as shown in Figure 8. If Figure $7 \mathrm{~b}$ is compared to Figure $7 \mathrm{a}$, it can bee seen that the voltage sag is occuring during the interval time from 0.25 second up to 0.78 second. Hence, it can be concluded that the addition of D-STATCON improves the response of the system by 0.13 second. The addition of D-STATCON can thus ameliorate the transient stability of the system.

The accompanying reactive power generation was related to the charging and discharging phenomena of the energy storage capacitor. During the occurrence of the voltage sag, the dc voltage values are displayed in Figure 9. It indicates that the capacitor was discharging during the voltage sag event.

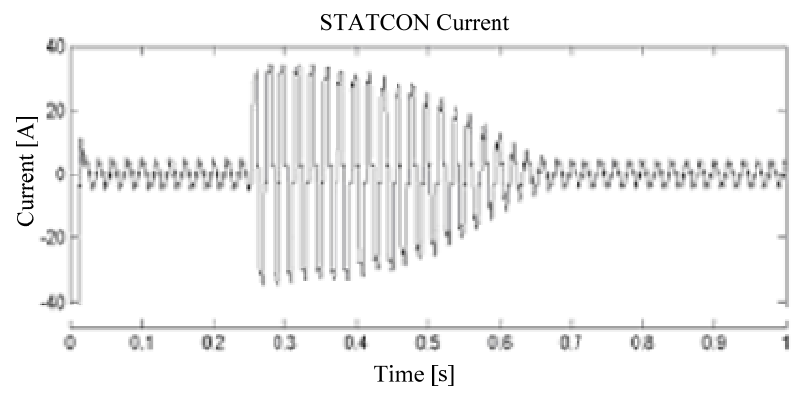

Figure 8. The D-STATCON current waveform

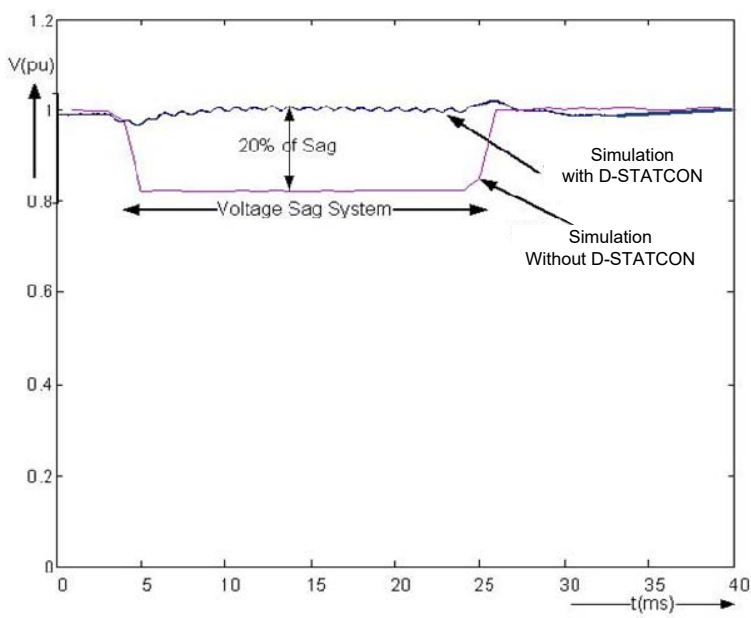

Figure 9. The voltage sag events

\section{CONCLUSION}

The objective to explore the behavior and compensation capability performance of a thyristor-based distribution static synchronous condenser through its model to mitigate voltage sags has been achieved. The model based on a phase-controlled thyristor circuit for simulation has been developed with the help of Matlab/simulink software. The simulation has been run on two cases of voltage sag occurrence, without and with D-STATCON, as a consequence of asynchronous motor starting in the system. It has been demonstrated that the D-STATCON implementation into the system could improve the voltage condition after sag event, both in terms of its magnitude and duration. The simulation results also demonstrate the fast response of DSTATCON to voltage sag phenomenon. The voltage improvement offered by a D-STATCON may significantly reduce the number of trips in the sensitive equipments after the voltage sag event 


\section{REFERENCES}

[1] C. Behera, et al., "Voltage Sag Mitigation Using Distributed Generation For An Industrial Distribution System," in 2018 IEEE International Conference on Power Electronics, Drives and Energy Systems (PEDES), pp. 1-6, 2018.

[2] A. Khergade, et al., "Analysis of Different Types of Voltage Sag and Its Effects on Adjustable Speed Drive," in 2018 IEEE International Conference on Power Electronics, Drives and Energy Systems (PEDES), pp. 1-6, 2018.

[3] Y. Li, et al., "Voltage Sag Study for a Practical Industrial Distribution Network," in Proceeding of 2006 International Conference on Power System Technology, pp. 1-4, 2006.

[4] S. Arias-Guzman, et al., "Analysis of voltage sag severity case study in an industrial circuit," in Proceeding of 2015 IEEE Industry Applications Society Annual Meeting, pp. 1-6, 2015.

[5] MHJ Bollen. Understanding power quality problems: Voltage Sags and Interruptions. New York: IEEE Press Series on Power Engineering, 2000.

[6] G. Yaleinkaya, et al., "Characterization of voltage sags in industrial distribution systems," IEEE Transactions on Industry Applications, vol. 34(4), pp. 682-688, 1998.

[7] J. C Das., "Application of STATCOM to an Industrial Distribution System Connected to a Weak Utility System," IEEE Transactions on Industry Applications, vol 52(6), pp. 5345-5354, 2016.

[8] B.Q. Khanh., "On Optimally Positioning a Multiple of Dynamic Voltage Restorers in Distribution System for Global Voltage Sag Mitigation," in 2019 IEEE Asia Power and Energy Engineering Conference (APEEC), pp. 137143, 2019.

[9] J.R. Ramamurthy, et al., "Mitigation of Motor Starting Voltage Sags Using Distribution-Class STATCOM," in 2018 IEEE/PES Transmission and Distribution Conference and Exposition (T\&D), pp. 1-9, 2018.

[10] P. Wang, et al., "Experimental investigation of voltage sag mitigation by an advanced static VAR compensator," IEEE Transactions on Power Delivery, vol. 13(4), pp. 1461-1467, 1998.

[11] M. Kuncoro and Iwa Garniwa, "DVR to Voltage Sag Mitigation Due to Induction Motor Starting and 3 Phase Fault," in 2018 5th International Conference on Information Technology, Computer, and Electrical Engineering (ICITACEE), pp.73-78, 2018.

[12] S. Hasan, et al., "Electromagnetic Field-Based Control of Distributed Generator Units to Mitigate Motor Starting Voltage Dips in Power Grids," IEEE Transactions on Applied Superconductivity, vol. 29(2), 2019.

[13] S. Hasan, et al., "A Coordinated Control Approach for Mitigation of Motor Starting Voltage Dip in Distribution Feeders," in 2018 IEEE Industry Applications Society Annual Meeting (IAS), pp. 1-6, 2018.

[14] L. Haijun, et al., "Preventing of transient voltage instability due to induction motor loads by static condenser," in Proceedings of 1994 IEEE International Conference on Industrial Technology - ICIT '94, pp. 827-831, 1994.

[15] W. Srirattanawichaikul and Y. Kumsuwan, "Static series-connected compensator with load-side connected shunt converter based on single-phase VSI for voltage sag mitigation," in Proceeding of 2016 IEEE Region 10 Conference (TENCON), pp. 2901-2904, 2016.

[16] M. Azharuddin and SR. Gaigowal, "Voltage regulation by grid connected PV-STATCOM," in Proceeding of 2017 International Conference on Power and Embedded Drive Control (ICPEDC), pp. 472-477, 2017.

[17] J. Rodrigues, et al., "The Role of Low-Voltage-Ride-Through Capability of Distributed Energy Resources for the Mitigation of Voltage Sags in Low Voltage Distribution Grids," in 2018 Power Systems Computation Conference (PSCC), pp. 1-7, 2018.

[18] J. Gunda, et al., "Mitigation of Voltage Sags and Swells by the Faraday Exchanger," in NEIS 2018 Conference on Sustainable Energy Supply and Energy Storage Systems, pp. 1-6, 2018.

[19] R. Mitra, et al., "Optimal selection of voltage sag mitigating devices for micro-level customer in distribution system," IET Renewable Power Generation, vol. 13(1), pp. 191-200, 2019.

[20] I.G. Park, et al., "A thyristor controlled static condenser with new double firing phase control," EEE Transactions on Industry Applications, vol. 33(6), pp. 1594-1600, 1997.

[21] P. Petitclair, et al., "Averaged modelling and nonlinear control of an ASVC (advanced static VAr compensator)," in PESC Record. 27th Annual IEEE Power Electronics Specialists Conference, vol. 1, pp. 753-758, 1996.

[22] H. Suyono, et al., "Optimization of the thyristor controlled phase shifting transformer using PSO algorithm," International Journal of Electrical and Computer Engineering (IJECE), vol. 8(6), pp. 5472-5483, 2018.

[23] J.E. Hill and W.T. Norris, "Exact analysis of a multipulse shunt converter compensator or Statcon. I. Performance," in IEE Proceedings - Generation, Transmission and Distribution, vol. 144(2), pp. 213-218, 1997.

[24] J.E. Hill and W.T. Norris, "Exact analysis of a multipulse shunt converter compensator or Statcon. II. Analysis," in IEE Proceedings - Generation, Transmission and Distribution, vol. 144(2), pp. 219-224, 1997.

[25] F. Shahnia, et al. Static Compensators (STATCOMs) in PowerSystems. New York: Springer, 2015.

[26] S.S. Kumar, et al., "A state of the art STATCON for instantaneous VAr compensation and harmonic suppression to enhance power quality," in CIGRE/IEEE PES International Symposium Quality and Security of Electric Power Delivery Systems, 2003. CIGRE/PES 2003, pp. 86-90, 2003.

[27] H. Suyono, et al., "Power system optimization of Static VAR Compensator using Novel Global Harmony Search Method," International Journal of Electrical and Electronic Engineering \& Telecommunications (IJEEET), vol. 8(1), pp. 26-32, 2019.

[28] G-W. Moon and S-H. Yoon, "Predictive current control of distribution static condenser (D-STATCON) for reactive power compensation in flexible AC transmission system (FACTS)," in PESC 98 Record. 29th Annual IEEE Power Electronics Specialists Conference (Cat. No.98CH36196), vol. 1, pp. 816-822, 1998.

Int J Pow Elec \& Dri Syst Vol. 10, No. 4, Dec 2019 : 2214 - 2221 
[29] M.A. Choudhry., "Network simulation with STATCON devices to avoid voltage collapse in the interconnected system," in Proceedings of the 2005 IEEE Symposium on Emerging Technologies, pp. 412-417, 2005.

[30] Y. Zhuang, et al., "Dynamic performance of a STATCON at an HVDC inverter feeding a very weak AC system," IEEE Transactions on Power Delivery, vol. 11(2), pp. 958-964, 1996.

[31] X. Zhou, "The Controller Design of STATCON Based on Direct Power Control," in Proceedings of 2012 AsiaPacific Power and Energy Engineering Conference, pp. 1-4, 2012.

\section{BIOGRAPHIES OF AUTHORS}

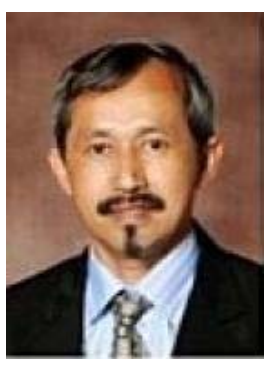

Hendri Masdi was born in West Sumatera province, Indonesia. He graduated with Sarjana Teknik (Bachelor of Engineering) from Universitas Negeri Padang, a state university in Indonesia, in 1989. He obtained his master degree in electrical engineering from Institut Teknologi Bandung (ITB), Indonesia in 2000. He got his PhD degree from the Electrical and Electronic Engineering Department, Faculty of Engineering, Universiti Putra Malaysia (UPM), Malaysia. Right now, he is with the Electrical Engineering Department of Universitas Negeri Padang, Indonesia, where he is the head of department. His research interests include power electronics, control and automation, renewable energy, and power systems.

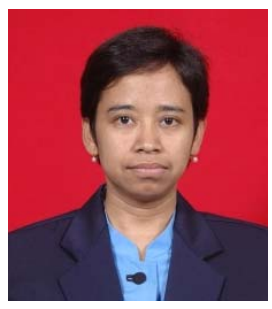

Rini Nur Hasanah was graduated in electrical engineering from Bandung Institute of Technology - Indonesia, got her postgraduate master degree in energy from the Swiss Federal Institute of Technology in Lausanne (EPFL), Switzerland, and got her doctoral degree from the same university.

She joined the Electrical Engineering department at Universitas Brawijaya, Indonesia in 1995 where she is currently the Chair of Electrical Power Engineering Section. Her research interests include electrical machines and drives, power electronics, rural electrification, renewable energy, energy management, and power systems.

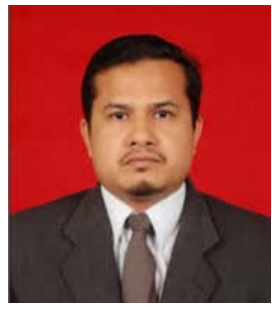

Hadi Suyono was born in Pamekasan, East Java, Indonesia in 1973. He graduated from the Department of Electrical Engineering at Universitas Brawijaya, Indonesia in 1996. He obtained his M.Eng and Ph.D. degrees from Universitas Gadjah Mada, Indonesia and Universiti Malaya, Malaysia, in 2000 and 2006 respectively. Since 2008, he has been with the Department of Electrical Engineering, Faculty of Engineering, Universitas Brawijaya, where he is the head of department right now. He is also the director of the Power System Engineering and Energy Management Research Group (PSeemRG) of Universitas Brawijaya. His major research interests are power system engineering, artificial intelligence, renewable energy and energy management.

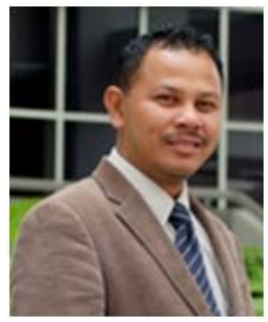

Ismail Bin Musirin obtained Bachelor of Electrical Engineering (Hons) in 1990 from Universiti Teknologi Malaysia, MSc in Pulsed Power Technology in 1992 from University of Strathclyde, United Kingdom and $\mathrm{PhD}$ in Electrical Engineering from Universiti Teknologi MARA (UiTM), Malaysia in 2005. He is currently Professor of Power System at the Faculty of Electrical Engineering, UiTM and the Director, Community of Research (CoRe), Advanced Computing and Communication (ACC), Institute of Research Management and Innovation, UiTM. He has authored and co-authored 2 books, over 300 papers in the international indexed journal and conferences. He is also an international journal reviewer for IEEE Transactions, Elsevier Science, WSEAS, John Wiley, IET and some other publishers. His research interest includes artificial intelligence, optimization techniques, power system analysis, renewable energy, distributed generation and power system stability.

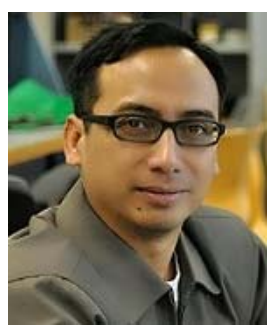

Taufik Taufik received his Doctor of Engineering from Cleveland State University. He joined the Electrical Engineering department at Cal Poly State University in 1999 where he is currently a tenured Full Professor and the Director of Electric Power Institute. He received numerous teaching awards, most notably the 2012 Outstanding Teaching Award from the American Society of Engineering Education - Pacific Southwest Section. He is a Senior Member of IEEE and has industry experience with several international companies. His areas of research include power electronics, power systems, rural electrification, energy harvesting, renewable energy and smart grid. He has published over 200 technical papers and journals, reports, books, course readers, and served on the editorial review boards of several journals. 